\title{
Iliac bone histomorphometry in adults and children with osteogenesis imperfecta
}

\author{
LG STE-MARIE,* SA CHARHON, C EDOUARD, MC CHAPUY, PJ MEUNIER \\ From Inserm Unité 234, Pathologie des Tissus Calcifiés, Faculté de Médecine Alexis Carrel, Lyon, France
}

SUMMARY Histomorphometric analysis was performed on transiliac undecalcified bone biopsies taken from eight adults and four children with osteogenesis imperfecta. Double tetracycline labelling done before the biopsy allowed measurement of the calcification rate in 11 patients. The adults, as well as the children, had thin iliac cortices and considerably decreased trabecular bone volume. In addition, the calcification rate was significantly reduced. Since the thickness index of osteoid seams was low or normal in all subjects, it indicated a reduced bone formation at the cellular level. In the adults, there was no significant increase in the parameters of bone resorption or in the bone formation rates at the basic multicellular unit and the tissue levels.

Thus the histomorphometric profile of iliac bone in osteogenesis imperfecta is characterised by cortical and trabecular osteoporosis with decreased activity of the individual osteoblasts. These findings would suggest the use of therapeutic agents stimulating bone formation rather than agents inhibiting bone resorption in osteogenesis imperfecta.

Osteogenesis imperfecta is a heterogeneous group of connective tissue disorders characterised by bone fragility and frequently associated with other features such as blue sclerae, opalescent teeth, and early hearing impairment.' Although there have been many studies on bone histology in osteogenesis imperfecta, the histopathogenesis of the osteopenia seen in this group of disorders is not well understood.

Many of these reports, especially the earlier ones, described histology of bone specimens obtained from various sites, mainly long bones. Moreover, the bone samples had often been taken during orthopaedic surgical procedures. ${ }^{23}$ Consequently, they might not have been truly representative of the basic bone remodelling of osteogenesis imperfecta because of the abnormal stress due to bone curvature..$^{3-5}$ In addition, patients were often immobilised and therefore had an additional cause of disturbed bone remodelling. ${ }^{6}$ More recent studies have been carried out on bone samples obtained from standardised biopsy sites - namely, the rib $^{5-9}$ and the iliac crest. ${ }^{40^{-12}}$ The rib, being essentially made up of cortical bone, is not adequate for the study of trabecular bone, whereas iliac crest allows detailed

\footnotetext{
* Dr Ste-Marie is a research fellow of the Canadian Medical Research Council.
}

Accepted for publication 13 June 1984 evaluation of trabecular bone remodelling. ${ }^{13}$ As these two bone envelopes might present differences in their remodelling, ${ }^{14}$ results from iliac crest biopsies could give additional information to those collected from rib biopsies. Besides the problem of adequacy of bone biopsy site, decalcification of the bone samples often used in older studies rendered impossible any valid evaluation of osteoid and thus of bone formation.

There are few published histomorphometric analyses of undecalcified bone in osteogenesis imperfecta using double tetracycline labelling for the measurement of bone formation rates. To date four rib studies, of which three are from the same group $^{7-9}$ and one from Albright et al, ${ }^{5}$ have been reported in patients with osteogenesis imperfecta. The sole study of iliac crest ${ }^{11}$ was performed in children only.

The various methodological differences might explain the conflicting results reported on bone remodelling; some authors concluded that there was increased bone resorption with or without decreased bone formation, ${ }^{579}$ whereas others found decreased bone formation with or without decreased bone resorption..$^{10-12}$

Since there is no available information on undecalcified iliac crest biopsies taken after double tetracycline labelling in adults with osteogenesis imperfecta, we report here dynamic data from eight 
Table 1 Details of patients studied

\begin{tabular}{|c|c|c|c|c|c|c|c|}
\hline Patients & Sex & Age (yrs) & $\begin{array}{l}\text { Family } \\
\text { history }\end{array}$ & $\begin{array}{l}\text { Long bone } \\
\text { fractures }\end{array}$ & $\begin{array}{l}\text { Vertebral crush } \\
\text { fractures }\end{array}$ & $\begin{array}{l}\text { Hearing } \\
\text { impairment }\end{array}$ & $\begin{array}{l}\text { Opalescent } \\
\text { teeth }\end{array}$ \\
\hline \multicolumn{8}{|l|}{ Children } \\
\hline C1 & $\mathbf{M}$ & 5 & 0 & 1 & 0 & 0 & + \\
\hline $\mathrm{C} 2$ & $\mathbf{M}$ & 12 & 0 & 6 & 1 & 0 & 0 \\
\hline C3 & $\mathbf{M}$ & 14 & 0 & 6 & 3 & 0 & 0 \\
\hline C4 & $\dot{M}$ & 17 & 0 & 13 & 5 & 0 & 0 \\
\hline \multicolumn{8}{|l|}{ Adults } \\
\hline A1 & $\mathbf{M}$ & 21 & 0 & 25 & 12 & + & NK \\
\hline A2 & $\mathbf{M}$ & 46 & 0 & 7 & 4 & 0 & NK \\
\hline A3 & $\mathbf{M}$ & 48 & + & 3 & 3 & + & NK \\
\hline A4 & $\mathbf{M}$ & 54 & + & 6 & 1 & + & + \\
\hline A5 & $F$ & 25 & + & 2 & 0 & 0 & 0 \\
\hline A6 & $\mathbf{F}$ & 32 & + & 7 & 0 & + & 0 \\
\hline A7 & $\mathbf{F}$ & 58 & + & 15 & 7 & 0 & 0 \\
\hline A8 & $\mathbf{F}$ & 69 & + & 14 & 14 & + & NK \\
\hline
\end{tabular}

NK = not known.

adults and four children suffering from mild osteogenesis imperfecta-type I or IV according to Sillence's classification.'

\section{Patients and methods}

PATIENTS (Table 1)

In this retrospective study 12 patients with osteogenesis imperfecta were selected on the basis of three criteria: firstly, a positive history of fractures sustained after minor trauma; secondly, blue sclerae; and thirdly, complete transiliac bone biopsy taken before treatment with agents such as calcitonin or sodium fluoride. Patients were classified as adults if their epiphyseal cartilages were closed. There were eight adults (four men and four women) with a mean age of 44.1 years and four children (all boys) with a mean age of $12 \cdot 0$ years (Table 1 ). A positive family history for osteogenesis imperfecta was found in six of the eight adults but in none of the four children. The number of long bone fractures varied from one to 25 per patient. The youngest patient $\mathrm{C} 1$, who experienced only one fracture before he was biopsied, was included because of the associated blue sclerae and opalescent teeth. Vertebral crush fractures were present in six adults and three children. Hearing impairment, tested by audiogram, was found in five adults. All the patients were ambulatory and had only mild or no incapacity. No patient was immobilised for a prolonged time before the biopsy. Causes of bone fragility such as hyperthyroidism, hyperparathyroidism, glucocorticoid excess, hypogonadism, malignant diseases, and renal insufficiency were excluded by physical examination or laboratory tests. Patient A2 had a history of chronic alcohol intake which postdated his fractures. Patient A7 had taken phenobarbital daily for 30 years.

\section{BIOCHEMISTRY}

Total serum calcium, phosphorus, alkaline phosphatase, immunoreactive parathyroid hormone, urinary calcium, and urinary hydroxypyroline were measured in all but two patients. In patient $\mathrm{C} 1$ only serum calcium and serum phosphate were measured, and in patient $\mathrm{C} 2$ immunoreactive parathyroid hormone was not measured. Total serum and urinary calcium were measured by a complexometric method. ${ }^{15}$ The normal adult range (mean \pm SD) was $9.8 \pm 0.3 \mathrm{mg} / 100 \mathrm{ml}$ for serum calcium and $197 \pm$ $89 \mathrm{mg} /$ day for urinary calcium. Serum phosphorus and serum alkaline phosphatase were measured by colorimetric methods. The normal adult range was $3.61 \pm 0.48 \mathrm{mg} / 100 \mathrm{ml}$ for serum phosphate and 2.7 \pm 1.0 Bodansky units for serum alkaline phosphatase. Total urinary hydroxyproline was assayed using a modification of the method of Kivirikko et al $;^{16}$ the normal adult range was $27.6 \pm 9.8 \mathrm{mg} / \mathrm{day}$. Serum immunoreactive parathyroid hormone was measured by $\mathrm{C}$ terminal radioimmunoassays: GP- 6 antibody (generous gift from Dr C Anast) was used in two cases and a commercial kit (CEA Oris) in eight patients.

\section{BONE HISTOMORPHOMETRY}

Horizontal transiliac crest bone biopsies were taken using a $7.5 \mathrm{~mm}$ inner diameter trephine at a standard site: $2 \mathrm{~cm}$ behind the anteriosuperior iliac spine and $2 \mathrm{~cm}$ below the summit of the crest. ${ }^{17}$ Tetracycline double labelling was performed before the biopsy with demethylchlortetracycline $(10$ to $15 \mathrm{mg} / \mathrm{kg} /$ day) administered according to the following schedule: two days on, 12 days off, and then four days on. The bone biopsies were performed between three and seven days after the second tetracycline administration. Samples were processed without decalcification in all cases, after embedding in 
Ward's bioplastic or in methylmethacrylate. Eight micrometre thick, serial non-consecutive sections were produced. Five sections were stained with solochrome cyanin $\mathrm{R}$ for measurement of osteoid parameters, four sections with Goldner's method for measurement of resorption parameters, and two sections with toluidine blue for measurement of trabecular osteoblastic surfaces. Four additional $20 \mu \mathrm{m}$ thick sections were mounted unstained and were used for the measurement of calcification rate and trabecular tetracycline labelled surfaces. The histomorphometric measurements were made manually using eyepiece graticules (point counting method for volume measurements, linear intercept method for surface measurements, and calibrated micrometer for distance measurements).

The following static parameters of bone remodelling were measured on the stained sections:

The trabecular bone volume is expressed as the percentage of trabecular bone tissue in the total spongy bone space. It was measured on five sections. Since the normal values change with sex and age ${ }^{18}$ results were compared with values obtained in sex and decade matched controls (total of 110 men and 62 women) all having suffered sudden death. ${ }^{19}$ As no control values for children are available in our laboratory, results in children with osteogenesis imperfecta were compared with values obtained from P Marie and F Glorieux (personal communication) in a group of 12 control children (age range 7-16 years).

The thickness of iliac cortices represents the mean thickness of the two cortices. The thickness of each cortex was determined by four equidistant measurements repeated on five sections. As for the trabecular bone volume, results were compared with values obtained by Courpron ${ }^{20}$ in sex and decade matched controls (total of 78 men and 28 women). No control values for children are available in our laboratory or in the published work.

The trabecular osteoid volume represents the percentage of total trabecular bone tissue occupied by osteoid.

The trabecular osteoid surfaces are expressed as the percentage of the total trabecular surfaces covered with osteoid. Because both trabecular osteoid volume and trabecular osteoid surface values change with sex and age in control adults, ${ }^{21}$ the results were compared with values of sex and decade matched controls (total of 58 men and 32 women).

The thickness index of osteoid seams represents the ratio of trabecular osteoid volume to trabecular osteoid surfaces $\times 100$. In normal adults (total of 108) this parameter does not change with age or sex. ${ }^{21}$

The trabecular osteoblastic surfaces are expressed as the percentage of total trabecular surfaces covered with osteoblasts. Results were compared with control values reported by Rasmussen and Bordier. ${ }^{22}$

The total osteoclastic resorption surfaces are defined as scalloped surfaces with or without osteoclasts. They are expressed as the percentage of the total trabecular surfaces. In adults, the normal values do not change with age or sex. ${ }^{23}$

The number of osteoclasts per square millimetre of trabecular bone section was counted. Normal values for adults were obtained from Rasmussen and Bordier. ${ }^{22}$

The mean wall thickness of trabecular bone packets could not be measured because of the insufficient number of completed packets related to the considerably reduced trabecular bone volume.

Based on the double tetracycline labelling, the following dynamic parameters were measured on the unstained sections:

The calcification rate was determined by dividing the average distance between the mid-points of the tetracycline labels (in micrometres) by the time interval between the two labelling periods ( 15 days). Calcification rate was therefore expressed in micrometres per day. The value was uncorrected for oblique cutting. All double labelled fluorescent sites seen in trabecular bone were measured. In patient C2 only one double labelled site was seen because of the considerable reduction in the trabecular bone volume. In patient $\mathrm{A} 2$ dynamic parameters were not measurable because of an error in the schedule of tetracycline administration. In control adults this parameter does not change with age or sex..$^{24}$ Control values for children were obtained from $P$ Marie and $\mathrm{F}$ Glorieux (personal communication).

The trabecular single labelled surfaces are expressed as the percentage of total trabecular surfaces covered by a single tetracycline label only.

The trabecular double labelled surfaces are expressed as the percentage of total trabecular surfaces covered by a double tetracycline label only.

The total labelled surfaces are defined as the sum of trabecular single and double labelled surfaces. Control values for these three parameters in adults were obtained from Vedi et al. ${ }^{25}$ In patient A5 the extent of the single labelled surfaces, and thus of total labelled surfaces, was not measurable because the second tetracycline label was too faint.

The bone formation rate at the tissue level, surface referent, is defined as the total labelled surfaces multiplied by calcification rate $^{26}$ and gives the amount of mineralised bone being made per unit of bone surface area of trabecular bone per day.

The bone formation rate at the basic multicellular unit level is defined as the ratio of total labelled sur- 
faces to trabecular osteoid surfaces multiplied by the calcification rate ${ }^{26}$ and gives the amount of mineralised bone being made per day per unit of osteoid covered surface. Control values of the bone formation rates in adults were obtained from Vedi et al. ${ }^{25}$

\section{STATISTICS}

In the adult group, statistical testing was performed on the histomorphometric parameters for which control values were measured in our laboratory. Individual values from patients were compared with normal mean values obtained in sex and decade matched controls by Wilcoxon's T test. For the other parameters, control values from published work 2225 are given for comparison only. In the group of children no statistical testing was performed because of the small number of patients, although control values obtained from a group of 12 normal children $(P$ Marie and F Glorieux, personal communication) are given as reference values.

\section{Results}

BIOCHEMICAL DATA (Table 2)

The adult patients had serum phosphate values in the normal range and serum calcium values in the lower range of normal. Serum alkaline phosphatase values were within the normal limits except for patient $\mathrm{A} 7$, who had a history of chronic intake of phenobarbital. All adult patients had urinary calcium values within the normal range. Urinary hydroxyproline was greater than the normal mean value +2 SD in two cases (A2 and A5). Serum immunoreactive parathyroid hormone values were within the normal range in the 10 patients in whom the measurement was performed.

Children had serum calcium, serum phosphate, and serum alkaline phosphatase values within the normal ranges for their ages. Urinary hydroxyproline excretion, when compared with published values of age and sex matched controls, ${ }^{27}$ was normal in two patients and significantly greater than normal in one (C3).

\section{BONE HISTOLOGY}

Static parameters of bone remodelling (Tables 3 and 4)

In the group of adults, the trabecular bone volume was considerably decreased $(p=0 \cdot 01)$ when compared with normal (Table 3). Six of eight patients had values lower than $11 \%$, which is considered to be the threshold below which vertebral crushes are likely to occur in osteoporotics. ${ }^{18}$ In addition, the thickness of iliac cortices was significantly decreased $(p<0.05)$. The trabecular osteoid volume was slightly but not significantly increased (only one patient had a trabecular osteoid volume value greater than the normal mean value $+2 \mathrm{SD}$ ). The trabecular osteoid surfaces were more than double $(2.26 \times)$ the normal mean value $(p<0.05)$. Thus the thickness index of osteoid seams in osteogenesis imperfecta was significantly decreased $(p<0.05)$. When compared with control values reported by Rasmussen and Bordier, ${ }^{22}$ four adults had trabecular osteoblastic surfaces greater than the normal mean value +2 SD. The parameters of resorption, total osteoclastic resorption surfaces and number of osteoclasts per square millimetre of trabecular bone section were slightly but not significantly increased.

In the group of children results were compared with control values given by $P$ Marie and F Glorieux (personal communication). All four children had low values of trabecular bone volume. Furthermore,

Table 2 Biochemical values

\begin{tabular}{|c|c|c|c|c|c|}
\hline Patients & $\begin{array}{l}\text { Serum calcium } \\
(\mathrm{mg} / 100 \mathrm{ml})\end{array}$ & $\begin{array}{l}\text { Serum phosphorus } \\
(\mathrm{mg} / 100 \mathrm{ml})\end{array}$ & $\begin{array}{l}\text { Serum alkaline phosphatase } \\
\text { (Bodansky units) }\end{array}$ & $\begin{array}{l}\text { Urinary calcium } \\
(m g / d a y)\end{array}$ & $\begin{array}{l}\text { Urinary hydroxyproline } \\
\text { (mg/day) }\end{array}$ \\
\hline $\begin{array}{l}\text { Children } \\
\text { C1 } \\
\text { C2 } \\
\text { C3 } \\
\text { C4 } \\
\text { Mean } \pm \text { SD }\end{array}$ & $\begin{array}{l}9 \cdot 6 \\
9 \cdot 5 \\
9 \cdot 9 \\
9 \cdot 7 \\
9 \cdot 7 \pm 0 \cdot 2\end{array}$ & $\begin{array}{l}4 \cdot 5 \\
5 \cdot 1 \\
4 \cdot 2 \\
4 \cdot 1 \\
4 \cdot 5 \pm 0 \cdot 4\end{array}$ & $\begin{array}{l}\text { NA } \\
9 \cdot 8 \\
10 \cdot 4 \\
9 \cdot 9 \\
10 \cdot 0 \pm 0 \cdot 3\end{array}$ & $\begin{array}{l}\text { NA } \\
22 \\
82 \\
22 \\
42 \cdot 0 \pm 34 \cdot 6\end{array}$ & $\begin{array}{l}\text { NA } \\
54 \cdot 7 \\
237 \cdot 3 \\
73 \cdot 7 \\
121 \cdot 9 \pm 100 \cdot 4\end{array}$ \\
\hline $\begin{array}{c}\text { Adults } \\
\text { A1 } \\
\text { A2 } \\
\text { A3 } \\
\text { A4 } \\
\text { A5 } \\
\text { A6 } \\
\text { A7 } \\
\text { A8 } \\
\text { Mean } \pm \text { SD } \\
\text { Controls }\end{array}$ & $\begin{array}{l}9 \cdot 7 \\
9 \cdot 8 \\
9 \cdot 8 \\
9 \cdot 2 \\
9 \cdot 3 \\
9 \cdot 0 \\
9 \cdot 6 \\
9 \cdot 4 \\
9 \cdot 5 \pm 0 \cdot 3 \\
9 \cdot 8 \pm 0 \cdot 3\end{array}$ & $\begin{array}{l}3 \cdot 9 \\
4 \cdot 5 \\
3 \cdot 8 \\
3 \cdot 4 \\
3 \cdot 0 \\
3 \cdot 1 \\
3 \cdot 4 \\
3 \cdot 1 \\
3 \cdot 5 \pm 0 \cdot 5 \\
3 \cdot 6 \pm 0 \cdot 5\end{array}$ & $\begin{array}{l}4 \cdot 0 \\
4 \cdot 5 \\
3 \cdot 0 \\
3 \cdot 5 \\
2 \cdot 7 \\
3 \cdot 4 \\
5 \cdot 6 \\
3 \cdot 7 \\
3 \cdot 8 \pm 0 \cdot 9 \\
2 \cdot 7 \pm 1 \cdot 0\end{array}$ & $\begin{array}{l}209 \\
60 \\
277 \\
338 \\
233 \\
147 \\
251 \\
89 \\
200 \pm 95 \\
197 \pm 89\end{array}$ & $\begin{array}{l}33 \cdot 2 \\
51 \cdot 0 \\
34 \cdot 7 \\
38 \cdot 0 \\
58 \cdot 8 \\
31 \cdot 1 \\
44 \cdot 8 \\
28 \cdot 3 \\
40 \cdot 0 \pm 10 \cdot 6 \\
27 \cdot 6 \pm 9 \cdot 8\end{array}$ \\
\hline
\end{tabular}

NA $=$ not available. 
Table 3 Trabecular bone volumes

\begin{tabular}{|c|c|c|c|}
\hline Patients & $\begin{array}{l}\text { Patient values } \\
(\%)\end{array}$ & $\begin{array}{l}\text { Control values } \\
\text { (\%) }\end{array}$ & $\begin{array}{l}\text { Difference } \\
\text { (\% of control value) }\end{array}$ \\
\hline $\begin{array}{l}\text { Children } \\
\text { C1 } \\
\text { C2 } \\
\text { C3 } \\
\text { C4 } \\
\text { Mean } \pm \text { SD }\end{array}$ & $\begin{array}{l}8 \cdot 4 \\
5 \cdot 2 \\
10 \cdot 2 \\
9 \cdot 2 \\
8 \cdot 3 \pm 2 \cdot 2\end{array}$ & $\begin{array}{l}\text { NA } \\
\text { NA } \\
\text { NA } \\
\text { NA } \\
28 \cdot 6 \pm 3 \cdot 8^{*}\end{array}$ & $-71 \cdot 0$ \\
\hline $\begin{array}{c}\text { Adults } \\
\text { Men } \\
\text { A1 } \\
\text { A2 } \\
\text { A3 } \\
\text { A4 }\end{array}$ & $\begin{array}{l}9 \cdot 7 \\
8 \cdot 6 \\
7 \cdot 4 \\
8 \cdot 2\end{array}$ & $\begin{array}{l}22 \cdot 4 \pm 4 \cdot 8 \dagger \\
19 \cdot 3 \pm 3 \cdot 1 \\
19 \cdot 3 \pm 3 \cdot 1 \\
19 \cdot 1 \pm 4 \cdot 7\end{array}$ & $\begin{array}{l}-56 \cdot 7 \\
-49 \cdot 7 \\
-61 \cdot 7 \\
-57 \cdot 1\end{array}$ \\
\hline $\begin{array}{l}\text { Women } \\
\text { A5 } \\
\text { A6 } \\
\text { A7 } \\
\text { A8 } \\
\text { Mean } \pm \text { SD }\end{array}$ & $\begin{array}{r}23 \cdot 2 \\
9 \cdot 9 \\
16 \cdot 7 \\
3 \cdot 1 \\
10 \cdot 9 \pm 6 \cdot 28\end{array}$ & $\begin{array}{l}23 \cdot 6 \pm 4 \cdot 1 \\
23 \cdot 3 \pm 4 \cdot 1 \\
20 \cdot 0 \pm 3 \cdot 6 \\
15 \cdot 3 \pm 4 \cdot 6 \\
20 \cdot 6 \pm 5 \cdot 0 \ddagger\end{array}$ & $\begin{array}{l}-1.7 \\
-57.5 \\
-16.5 \\
-79.7 \\
-47.6 \pm 25.6\end{array}$ \\
\hline
\end{tabular}

* Control value in 12 children from P Marie and F Glorieux (personal communication)

tControl value (mean $\pm \mathrm{SD}$ ) in sex and decade matched subjects for adult patients.

$\ddagger$ Mean \pm SD of all adult controls.

$\S p=0.01$ (Wilcoxon's T test).

trabecular osteoid surfaces were increased in all cases, whereas trabecular osteoid volume was high in only two children. The thickness index of osteoid seams was therefore in the normal range in these two patients but low in the other two. No evidence of increased total osteoclastic resorption surfaces or of an increased number of osteoclasts per square millimetre of trabecular bone section was found.

Dynamic parameters of bone remodelling (Table 5) In the group of seven adults in whom calcification rate was measured, six had values equal to or less than the normal mean value $-2 \mathrm{SD}$-that is, a significant decrease $(p<0.05)$. The association of decreased calcification rate and thickness index of osteoid seams reflects a diminished bone matrix production at the osteoblast level.

The total labelled surfaces as well as the trabecular double labelled surfaces were within the range of published control values. ${ }^{25}$ Therefore, because of the low calcification rate bone formation rates at both the tissue level and at the basic multicellular unit level were decreased when compared with published control values.

The children also had low values of calcification rate when compared with values of age matched controls (P Marie and F Glorieux). Thus the children with osteogenesis imperfecta, like the adult patients, had decreased calcification rates associated with thickness indexes of osteoid seams, which tended to be decreased.

Table 4 Static parameters of bone remodelling

\begin{tabular}{|c|c|c|c|c|c|c|c|}
\hline Patients & $T I C(\mu \mathrm{m})$ & TOV (\%) & TOS (\%) & TIOS & TORS (\%) & $O C / \mathrm{mm}^{2}$ & TObS (\%) \\
\hline $\begin{array}{l}\text { Children } \\
\text { C1 } \\
\text { C2 } \\
\text { C3 } \\
\text { C4 } \\
\text { Mean } \pm \text { SD } \\
\text { Controls* }\end{array}$ & $\begin{array}{l}925 \\
670 \\
880 \\
730 \\
801 \pm 121 \\
\text { NA }\end{array}$ & $\begin{array}{l}9 \cdot 7 \\
3 \cdot 5 \\
7 \cdot 4 \\
3 \cdot 8 \\
6 \cdot 1 \pm 3 \cdot 0 \\
4 \cdot 0 \pm 1 \cdot 4\end{array}$ & $\begin{array}{l}56 \cdot 6 \\
41 \cdot 5 \\
46 \cdot 2 \\
41 \cdot 5 \\
46 \cdot 5 \pm 7 \cdot 1 \\
21 \cdot 6 \pm 8 \cdot 0\end{array}$ & $\begin{array}{l}17 \cdot 1 \\
8 \cdot 4 \\
16 \cdot 0 \\
9 \cdot 2 \\
12 \cdot 7 \pm 4 \cdot 5 \\
\text { NA }\end{array}$ & $\begin{array}{l}8 \cdot 3 \\
2 \cdot 7 \\
4 \cdot 7 \\
6 \cdot 9 \\
5 \cdot 7 \pm 2 \cdot 5 \\
7 \cdot 6 \pm 1 \cdot 7\end{array}$ & $\begin{array}{l}0.92 \\
0.26 \\
0.24 \\
0.38 \\
0.45 \pm 0.32 \\
0.80 \pm 0.43\end{array}$ & $\begin{array}{l}31 \cdot 4 \\
11 \cdot 4 \\
25 \cdot 5 \\
10 \cdot 8 \\
19 \cdot 8 \pm 10 \cdot 3 \\
7 \cdot 0 \pm 3 \cdot 3\end{array}$ \\
\hline \multicolumn{8}{|l|}{$\begin{array}{r}\text { Adults } \\
\text { Men }\end{array}$} \\
\hline $\begin{array}{l}\text { Controls } \dagger \\
\text { A1 } \\
\text { A2 } \\
\text { A3 } \\
\text { A4 } \\
\text { Women }\end{array}$ & $\begin{array}{r}1025 \pm 297 \\
660 \\
350 \\
555 \\
1080\end{array}$ & $\begin{array}{l}3 \cdot 1 \pm 1.9 \\
3 \cdot 1 \\
0 \cdot 8 \\
2 \cdot 4 \\
3 \cdot 7\end{array}$ & $\begin{array}{l}16 \cdot 0 \pm 7 \cdot 8 \\
23 \cdot 5 \\
7 \cdot 3 \\
20 \cdot 9 \\
39 \cdot 7\end{array}$ & $\begin{array}{l}19 \cdot 2 \pm 4 \cdot 5 \\
13 \cdot 2 \\
11 \cdot 0 \\
11 \cdot 5 \\
9 \cdot 3\end{array}$ & $\begin{array}{l}3 \cdot 6 \pm 1 \cdot 1 \\
7 \cdot 0 \\
1 \cdot 3 \\
3 \cdot 2 \\
6 \cdot 9\end{array}$ & $\begin{array}{l}\ddagger \\
0 \cdot 33 \\
0 \cdot 18 \\
0 \cdot 05 \\
0 \cdot 26\end{array}$ & $\begin{array}{r}\S \\
6 \cdot 3 \\
2 \cdot 4 \\
5 \cdot 7 \\
13 \cdot 7\end{array}$ \\
\hline $\begin{array}{l}\text { Controls } \dagger \\
\text { A5 } \\
\text { A6 } \\
\text { A7 } \\
\text { A8 } \\
\text { Mean } \pm \text { SD } \|\end{array}$ & $\begin{array}{l}1057 \pm 348 \\
735 \\
825 \\
495 \\
570 \\
659 \pm 2249\end{array}$ & $\begin{array}{l}1 \cdot 9 \pm 1 \cdot 1 \\
3 \cdot 5 \\
3 \cdot 7 \\
3 \cdot 8 \\
6 \cdot 5 \\
3 \cdot 4 \pm 1 \cdot 6\end{array}$ & $\begin{array}{l}10 \cdot 3 \pm 5 \cdot 9 \\
38 \cdot 1 \\
18 \cdot 5 \\
39 \cdot 7 \\
43 \cdot 3 \\
28 \cdot 9 \pm 13 \cdot 19\end{array}$ & $\begin{array}{l}18 \cdot 4 \pm 2 \cdot 7 \\
9 \cdot 2 \\
20 \cdot 0 \\
9 \cdot 6 \\
15 \cdot 0 \\
12 \cdot 4 \pm 3 \cdot 7 \pi\end{array}$ & $\begin{array}{l}3 \cdot 6 \pm 1 \cdot 1 \\
6 \cdot 7 \\
6 \cdot 7 \\
9 \cdot 7 \\
2 \cdot 2 \\
5 \cdot 5 \pm 2 \cdot 9\end{array}$ & $\begin{array}{l}\ddagger \\
0.51 \\
0.33 \\
0.56 \\
0.24 \\
0.31 \pm 0.17\end{array}$ & $\begin{array}{l}\S \\
12 \cdot 7 \\
9 \cdot 3 \\
16 \cdot 0 \\
13 \cdot 8 \\
10 \cdot 0 \pm 4 \cdot 8\end{array}$ \\
\hline
\end{tabular}

TIC = thickness of iliac cortices; TOV = trabecular osteoid volume; TOS = trabecular osteoid surfaces; TIOS = thickness index of osteoid seams; TORS = total osteoclastic resorption surfaces; $\mathrm{OC} / \mathrm{mm}^{2}=$ number of osteoclasts per square millimetre of trabecular bone section; TObS $=$ trabecular osteoblastic surfaces. $\mathrm{NA}=$ not available

* Mean \pm SD from P Marie and F Glorieux (personal communication).

tControl values (mean \pm SD) in sex and decade matched subjects.

$\ddagger$ Control value $=0.20 \pm 0.09$ (mean \pm SD) from Rasmussen and Bordier. ${ }^{22}$

\$Control value $=5.1 \pm 3.0 \%$ (mean \pm SD) from Rasmussen and Bordier. ${ }^{22}$

Mean value of the eight adult patients.

ip $<0.05$ (Wilcoxon's T test). 
Table 5 Dynamic parameters of bone remodelling

\begin{tabular}{|c|c|c|c|c|c|c|}
\hline Patients & $C R(\mu \mathrm{m} /$ day $)$ & $S L S(\%)$ & $D L S(\%)$ & $T L S(\%)$ & $\begin{array}{l}B F R_{(\text {tissue })} \\
\left(\mu m^{3} / \mu m^{2} / d a y\right)\end{array}$ & $\begin{array}{l}B F R_{(B M U)} \\
\left(\mu m^{3} / \mu m^{2} / \text { day }\right)\end{array}$ \\
\hline $\begin{array}{l}\text { Children } \\
\text { C1 } \\
\text { C2 } \\
\text { C3 } \\
\text { C4 } \\
\text { Mean } \pm \text { SD } \\
\text { Controls* }\end{array}$ & $\begin{array}{l}0.70 \\
0.48 \\
1 \cdot 08 \\
0 \cdot 56 \\
0.71 \pm 0.27 \\
1 \cdot 31 \pm 0.38\end{array}$ & $\begin{array}{l}42 \cdot 2 \\
2 \cdot 2 \\
16 \cdot 8 \\
17 \cdot 9 \\
19 \cdot 8 \pm 16 \cdot 6 \\
\text { NA }\end{array}$ & $\begin{array}{l}13 \cdot 1 \\
7 \cdot 1 \\
22 \cdot 8 \\
15 \cdot 4 \\
14 \cdot 6 \pm 6 \cdot 5 \\
\text { NA }\end{array}$ & $\begin{array}{l}55 \cdot 3 \\
9 \cdot 3 \\
39 \cdot 6 \\
33 \cdot 3 \\
34 \cdot 4 \pm 19 \cdot 1 \\
\text { NA }\end{array}$ & $\begin{array}{l}0 \cdot 387 \\
0 \cdot 045 \\
0 \cdot 428 \\
0 \cdot 186 \\
0 \cdot 262 \pm 0 \cdot 179 \\
\mathrm{NA}\end{array}$ & $\begin{array}{l}0 \cdot 684 \\
0 \cdot 107 \\
0 \cdot 926 \\
0 \cdot 446 \\
0 \cdot 541 \pm 0.349 \\
\text { NA }\end{array}$ \\
\hline $\begin{array}{r}\text { Adults } \\
\text { Men }\end{array}$ & & & & & & \\
\hline $\begin{array}{l}\text { Controls } \dagger \\
\text { A1 } \\
\text { A2 } \\
\text { A3 } \\
\text { A4 }\end{array}$ & $\begin{array}{l}0.72 \pm 0.12 \\
0 \cdot 41 \\
\mathrm{NM} \\
0 \cdot 43 \\
0.48\end{array}$ & $\begin{array}{l}9 \cdot 5 \pm 4 \cdot 5 \\
4 \cdot 6 \\
\text { NM } \\
1 \cdot 3 \\
3 \cdot 3\end{array}$ & $\begin{array}{l}8 \cdot 3 \pm 5 \cdot 5 \\
6 \cdot 7 \\
\text { NM } \\
2 \cdot 3 \\
12 \cdot 7\end{array}$ & $\begin{array}{l}17 \cdot 7 \pm 7 \cdot 8 \\
11 \cdot 3 \\
\text { NM } \\
3 \cdot 6 \\
16 \cdot 0\end{array}$ & $\begin{array}{l}0 \cdot 102 \pm 0 \cdot 046 \\
0 \cdot 046 \\
\mathrm{NM} \\
0 \cdot 015 \\
0 \cdot 077\end{array}$ & $\begin{array}{l}0 \cdot 532 \pm 0 \cdot 463 \\
0 \cdot 197 \\
\mathrm{NM} \\
0 \cdot 074 \\
0 \cdot 193\end{array}$ \\
\hline $\begin{array}{l}\text { Women } \\
\text { Controls } \dagger \\
\text { A5 } \\
\text { A6 } \\
\text { A7 } \\
\text { A8 } \\
\text { Mean } \pm \text { SD } \ddagger\end{array}$ & $\begin{array}{l}0 \cdot 72 \pm 0.12 \\
0 \cdot 64 \\
0 \cdot 42 \\
0 \cdot 46 \\
0 \cdot 35 \\
0 \cdot 46 \pm 0.098\end{array}$ & $\begin{array}{l}8 \cdot 9 \pm 5 \cdot 0 \\
\text { NM } \\
4 \cdot 6 \\
5 \cdot 8 \\
7 \cdot 4 \\
4 \cdot 5 \pm 2 \cdot 1\end{array}$ & $\begin{array}{l}9 \cdot 5 \pm 6 \cdot 7 \\
\text { NM } \\
12 \cdot 9 \\
5 \cdot 3 \\
2 \cdot 6 \\
7 \cdot 1 \pm 4 \cdot 7\end{array}$ & $\begin{array}{l}18.5 \pm 8.9 \\
\text { NM } \\
17.5 \\
11 \cdot 1 \\
10.0 \\
11.6 \pm 4.9\end{array}$ & $\begin{array}{l}0 \cdot 112 \pm 0 \cdot 056 \\
\mathrm{NM} \\
0 \cdot 074 \\
0 \cdot 051 \\
0 \cdot 035 \\
0 \cdot 050 \pm 0 \cdot 024\end{array}$ & $\begin{array}{l}0 \cdot 637 \pm 0 \cdot 406 \\
\text { NM } \\
0 \cdot 397 \\
0 \cdot 129 \\
0 \cdot 081 \\
0 \cdot 179 \pm 0 \cdot 119\end{array}$ \\
\hline
\end{tabular}

CR = calcification rate; SLS = trabecular single labelled surfaces; DLS = trabecular double labelled surfaces; TLS = total labelled surfaces; BFR (tissue) = bone formation rate at the tissue level; BFR(BMU) = bone formation rate at the basic multicellular unit level; NA $=$ not available; $\mathbf{N M}=$ not measurable.

${ }^{*}$ Control values (mean $\pm \mathrm{SD}$ ) from $\mathrm{P}$ Marie and F Glorieux (personal communication).

tControl values (mean \pm SD) are from Vedi $e t$ al, ${ }^{25}$ except for calcification rate.

$¥$ Mean value of all adult patients.

$\S p<0.05$ (Wilcoxon's T test).

\section{Discussion}

These data show that, in agreement with previous studies of rib biopsies ${ }^{59}$ as well as of iliac crest, ${ }^{1011}$ patients with osteogenesis imperfecta have a decreased amount of trabecular bone and thin cortices. In addition to the well known thinning of bone cortices which probably explains the high incidence of long bone fractures in patients with osteogenesis imperfecta, it is notable that the iliac trabecular bone volume was lower than the vertebral fracture threshold ${ }^{18}$ in 10 of 12 patients. This could account for the presence of vertebral crushes in six adults and three children. Besides this reduced amount of bone, however, qualitative abnormalities of collagenous and non-collagenous components of bone $^{28-31}$ might play a part in the incidence of fractures.

The other common histomorphometric findings in our patients with osteogenesis imperfecta were a decrease (of $34 \%$ of control value) in the thickness index of osteoid seams associated with a decrease in the calcification rate (of $36 \%$ of control value). None of the adults and only two children had thickness indexes of osteoid seams and calcification rates in the normal range. This is typical of situations in which the bone matrix apposition by the osteoblasts is reduced, such as in corticosteroid induced osteoporosis $^{32}$ or hypogonadism. ${ }^{33}$ This decreased osteoblastic activity might be a characteristic his tomorphometric finding in osteogenesis imperfecta patients, both children and adults. Similar findings have been reported by Baron et al ${ }^{11}$ in iliac crest biopsies of nine children suffering from osteogenesis imperfecta tarda. Thin osteoid seams have also been found by Riley et $a^{10}$ and Stoss ${ }^{12}$ in iliac crest biopsies of patients. A decreased calcification rate has been found by Villaneuva and Frost $^{9}$ in rib biopsies of nine patients with osteogenesis imperfecta. Two studies, however, have reported normal or increased calcification rates. In one of them, ${ }^{3}$ the bone specimens were taken from sclerotic zones of long bones during surgical treatment for limb deformities. But as noted above, such areas are not suitable for analysing basic bone changes of osteogenesis imperfecta. In the other report, performed on rib biopsies of eight children and one adult, Albright $e t a^{5}$ found normal to slightly increased calcification rates. Suggestions for an impaired osteoblastic activity in osteogenesis imperfecta also come from studies using other methods. Doty and Matthews ${ }^{34}$ found in an electron microscopy and enzyme histochemistry study that only osteoblasts presented abnormal features, whereas the osteocytes and the osteoclasts were normal. Osteoblasts were reported to have large glycogen deposits in their cytoplasm, together 
with dense inclusions within the Golgi apparatus and low activities of alkaline phosphatase and adenosine monophosphatase in their membranes. In an electron microscopical study, Stoss ${ }^{12}$ reported osteoblasts with dilated endoplasmic reticulum and enlarged Golgi apparatus. Yet, they were associated with thin osteoid and reduced mineralisation, which is consistent with an altered osteoblastic function. Thus osteopenia in osteogenesis imperfecta could be related, at least in part, to a decreased osteoblastic activity at the cellular level.

In addition to the evaluation of the activity at the cellular level one has to examine phenomena at higher levels of organisation-that is, at the bone remodelling unit level and at the tissue level-in an attempt to find the precise mechanisms of osteopenia. As first described by Frost, ${ }^{35}$ the bone remodelling process results from the tightly coupled osteoclastic and osteoblastic activities in a "basic multicellular unit." Each basic multicellular unit cycle is characterised by the resorption of a certain amount of bone followed by the deposition of a certain amount of newly formed bone. An increase in the birthrate of basic multicellular units corresponding to a high turnover state will be reflected by an increase in the number of osteoclasts and osteoblasts associated with an increase in the extent of bone resorption and formation surfaces. The gain or loss of bone tissue is the direct consequence of cumulative bone balance occurring at the individual basic multicellular unit level. To date, no method is available to quantify dynamically the amount of bone resorbed. The amount of bone formed at the basic multicellular unit level as well as at the tissue level, however, can be measured using double tetracycline labelling. ${ }^{26}$ In the analysis of data on bone remodelling in osteogenesis imperfecta it seems preferable to separate children from adults because bone turnover in these two age groups is different.

When assessed by biochemical markers, conflicting results have been reported on the bone turnover in children with osteogenesis imperfecta. Urinary hydroxyproline, which reflects bone resorption, is not consistently raised. It was increased in some cases, ${ }^{11}{ }^{36-38}$ whereas other authors reported normal values $^{39-44}$ or even decreased values. ${ }^{10}$ Apart from the fact that urinary hydroxyproline is not a specific or sensitive marker of bone resorption, it is difficult to find adequate controls in children because of the wide range of normal values and because of the peaks associated with rapid growth periods such as the first two years and during adolescence. ${ }^{27}{ }^{36}$ When compared with published control values ${ }^{27}$ two of our patients had normal values and one (C4) had a value greater than the normal mean $+2 \mathrm{SD}$ for his age. Serum alkaline phosphatase values, which reflect in part bone formation, have also been reported to be increased, ${ }^{374345}$ but were normal in most cases $^{11.40-4246}$ when compared with age matched controls. Thus, there is no clear biochemical evidence of increased bone turnover, either increased bone resorption or increased bone formation.

Based on histomorphometric analyses performed on bone samples obtained from standard biopsy sites, bone turnover has often been reported to be increased in children with osteogenesis imperfecta. In rib biopsies, Albright et $a^{5}$ found increased resorption and osteoid surfaces in children with osteogenesis imperfecta when compared with age matched controls. In decalcified iliac crest biopsies, Falvo and Bullough ${ }^{4}$ reported a slight increase in resorption surfaces, but Riley et $\mathbf{l}^{10}$ found in undecalcified iliac crest biopsies that resorption surfaces as well as osteoid surfaces were below normal. Based on tetracycline labelling, Villanueva and Frost ${ }^{9}$ showed that in rib biopsies of four children with osteogenesis imperfecta, the bone formation rate was low or normal in three cases and increased in only one. More recently, Baron et al ${ }^{11}$ reported in undecalcified iliac crest biopsies of nine children with osteogenesis imperfecta increased bone formation and resorption surfaces. From the increase in osteoblastic surfaces, which was greater than the observed decrease in calcification rate, they inferred an increase in "bone formation rate." They therefore suggested that the decreased amount of bone matrix formed by individual osteoblasts would be compensated for by an increase in the number of osteoblasts. This does not necessarily imply, however, that the bone tissue balance is not negative, since the amount of bone resorbed cannot be quantified. If there is a negative balance at the basic multicellular unit level, as in the physiological state ${ }^{47}$ any increment in the birthrate of new basic multicellular units would magnify the bone loss by increasing the number of elemental deficits. Because of the small number of children in reported studies, including ours, conclusions on bone turnover in children with osteogenesis imperfecta remain unclear.

In adult patients, as in children, published results of biochemical indexes of bone turnover are conflicting. Urinary hydroxyproline was either increased ${ }^{36} 48$ or normal. ${ }^{42349}$ Serum alkaline phosphatase values were reported to be increased in some patients ${ }^{45}$ but normal in most studies. ${ }^{71-434648}$ Thus available biochemical data do not point clearly to an increased bone turnover in adults with osteogenesis imperfecta. In the published work, bone histomorphometry has been performed in only a few adult patients with osteogenesis imperfecta. In three studies $^{4} 5^{10}$ analysing small numbers of adults (one 
to three cases in each study), bone resorption as well as osteoid surfaces were normal or slightly increased. The only published data on bone formation rates in adult patients with osteogenesis imperfecta were obtained in rib biopsies by Frost's group. ${ }^{7-9}$ They have shown in five adult patients that despite a small decrease in calcification rate, the bone formation rate was increased to 2.7 to 7.8 times the normal value. ${ }^{9}$ In the present study, resorption surfaces were not significantly increased. Moreover, we were unable to find in iliac trabecular bone an increase in bone formation rate. When compared with published control values for adults both the tissue and the basic multicellular unit bone formation rates were normal in each patient. Increased bone turnover, however, as assessed by an increase in the number of osteoclasts or in the extent in the osteoblastic surfaces was found in half of the patients. Whether the discrepancies between reported findings and ours are due to differences between cortical and trabecular bone remodelling or to the heterogeneity of the disease, or both, cannot be determined.

In conclusion, the histomorphometric profile of iliac bone in osteogenesis imperfecta is characterised, in both adults and children, by a low trabecular bone volume, thin cortices, and a depression in osteoblastic activity at the cellular level, as indicated by thin osteoid seams and decreased calcification rate. In adults, there is no evidence of a significant increase in resorption parameters, nor in the bone formation rates at the basic multicellular unit and the tissue levels. According to these findings, a reappraisal of the rationale for the use of antiosteoclastic agents in patients with osteogenesis imperfecta is required, at least for adult patients. In contrast, agents stimulating bone formation such as fluoride, which is able to increase trabecular bone mass in osteoporotics ${ }^{50}$ could be of greater benefit. There is no proof, however, that osteoblasts of patients with osteogenesis imperfecta could respond to fluoride.

The authors wish to thank Mrs Christine Fourneret for expert secretarial work.

\section{References}

' Sillence D. Osteogenesis imperfecta: an expanding panorama of variants. Clin Orthop 1981;159:11-25.

${ }^{2}$ Robichon J, Germain JP. Pathogenesis of osteogenesis imperfecta. Can Med Assoc J 1968;99:975-9.

${ }^{3}$ Lee WR. A quantitative microscopic study of bone formation in a normal child and in two children suffering from osteogenesis imperfecta. In: Richelle LJ, Dallemagne MJ, eds. Proceedings of the second European symposium on calcified tissues. Les Congrès et Colloques de l'Université de Liège, Belgique, 1964:451-63.
${ }^{4}$ Falvo KA, Bullough PG. Osteogenesis imperfecta: a histometric analysis. J Bone Joint Surg (Am) 1973;55:275-86.

${ }^{5}$ Albright JP, Albright JA, Crelin ES. Osteogenesis imperfecta tarda. The morphology of rib biopsies. Clin Orthop 1975; 108:204-13.

${ }^{6}$ Minaire P, Meunier PJ, Edouard C. Quantitative histological data on disuse osteoporosis. Comparison with biological data. Calcif Tissue Res 1974;17:57-73.

' Jett S, Ramser JR, Frost HM, Villanueva AR. Bone turnover and osteogenesis imperfecta. Arch Pathol 1966;81:112-6.

${ }^{8}$ Ramser JR, Villanueva AR, Pirok D, Frost HM. Tetracyclinebased measurement of bone dynamics in 3 women with osteogenesis imperfecta. Clin Orthop 1966;49:151-62.

${ }^{9}$ Villanueva AR, Frost HM. Bone formation in human osteogenesis imperfecta, measured by tetracycline bone labelling. Acta Orthop Scand 1970;41:531-8.

${ }^{10}$ Riley FC, Jowsey J, Brown DM. Osteogenesis imperfecta: morphologic and biochemical studies of connective tissue. Pediatr Res 1973;9:757-68.

" Baron R, Gertner JM, Lang R, Vignery A. Increased bone turnover with decreased bone formation by osteoblasts in children with osteogenesis imperfecta tarda. Pediatr Res 1983; 17:204-7.

${ }_{12}$ Stoss $\mathrm{H}$. The pathomorphological inhomegeneity of osteogenesis imperfecta. Calcif Tissue Int 1983;35(suppl): A-13.

${ }^{13}$ Meunier PJ. Bone biopsy in diagnosis of metabolic bone disease. In: Cohn DV, Talmage RV, Les Matthews J, eds. Hormonal control of calcium metabolism. Proceedings of the seventh parathyroid conference. Amsterdam: Excerpta Medica 1981:109-17.

${ }^{14}$ Epker BN, Frost HM. A histological study of remodeling at the periosteal, haversian canal, cortical endosteal, and trabecular endosteal surfaces in human rib. Anat Rec 1965;152:129-35.

is Dielh $\mathrm{H}$, Ellingboe J. Indicator for titration of calcium in presence of magnesium using disodium dihydrogene ethylene diamine tetracetate. Anal Chem 1956;28:882-4.

${ }^{16}$ Firschein HE, Shill JP. The determination of total hydroxy proline in urine and bone extracts. Anal Biochem 1966; 14:296-304.

${ }^{17}$ Bordier PH, Matrajt H, Miravet L, Hioco D. Mesure histologique de la masse osseuse et de la résorption des travées osseuses. Path Biol (Paris) 1964; 12:1238-43.

${ }^{18}$ Meunier PJ, Courpron P, Edouard C, Bernard J, Bringuier JP, Vignon G. Physiological senile involution and pathological rarefaction of bone: quantitative and comparative histological data. Clin Endocrinol Metab 1973;2:239-56.

${ }^{19}$ Courpron P, Meunier PJ, Bressot C, Giroux JM. Amount of bone in iliac crest biopsy. Significance of the trabecular bone volume. Its values in normal and in pathological conditions. In: Meunier PJ, ed. Bone histomorphometry. Second international workshop. Toulouse, France: Société de la Nouvelle Imprimerie Fournié; 1976:39-53.

${ }^{20}$ Courpron P. Données histologiques quantitatives sur le vieillissement osseux humain. Thesis Lyon, 1972.

${ }^{21}$ Meunier PJ, Edouard C, Richard D, Laurent J. Histomorphometry of osteoid tissue. The hyperosteoidoses. In: Meunier PJ, ed. Bone histomorphometry. Second international workshop. Toulouse, France: Société de la Nouvelle Imprimerie Fournié, 1976:249-62.

22 Rasmussen $\mathrm{H}$, Bordier P. The physiological and cellular basis of metabolic bone disease. Baltimore: Williams and Wilkins, 1974.

${ }^{23}$ Meunier PJ, Edouard C, Courpron P. Morphometric analysis of trabecular bone resorption surfaces in normal iliac bone. In Jaworski ZFG, ed. Bone morphometry. Ottawa: University of Ottawa Press, 1976:156-60.

${ }^{24}$ Meunier PJ. Disturbances in morphology and dynamics of the remodelling process in pagetic bone. In: MacIntyre I, ed. Human calcitonin and Paget's disease. Bern: Huber, 1976: 78-89. 
${ }^{25}$ Vedi S, Compston JE, Webb A, Tighe JR. Histomorphometric analysis of dynamic parameters of trabecular bone formation in the iliac crest of normal British subjects. Metab Bone Dis Relat Res 1983;5:69-74.

${ }^{26}$ Melsen F, Mosekilde L. Tetracycline double-labelling of iliac trabecular bone in 41 normal adults. Calcif Tiss Res 1978; 26: 99-102.

${ }^{27}$ Clark S, Zorab PA. Hydroxyproline centiles for normal adolescent boys and girls. Clin Orthop 1978;137:217-26.

${ }_{28}$ Teitelbaum SL, Kraft WJ, Lang R, Avioli LV. Bone collagen aggregation abnormalities in osteogenesis imperfecta. Calcif Tissue Res 1974;17:75-9.

${ }^{29}$ Shapiro JR, Triche T, Rowe D, Munabi A, Cattell HS, Schlesinger S. Osteogenesis imperfecta and Paget s disease of bone. Biochemical and morphologic studies. Arch Intern Med 1983; 143:2250-7.

${ }^{30}$ Byers PH, Bonadio JF, Steinmann B. Osteogenesis imperfecta: update and perspective. Am J Med Genet 1984;17:429-35.

${ }^{31}$ Dickson IR, Millar EA, Veis A. Evidence for abnormality of bone-matrix proteins in osteogenesis imperfecta. Lancet 1975;ii:586-7.

${ }^{32}$ Bressot C, Meunier PJ, Chapuy MC, Lejeune E, Edouard C, Darby AJ. Histomorphometric profile, pathophysiology and reversibility of corticosteroid-induced osteoporosis. Metab Bone Dis Relat Res 1979;1:303-11.

${ }^{33}$ Delmas P, Meunier PJ. L'ostéoporose au cours du syndrome de Klinefelter. Nouv Presse Med 1981;10:687-90.

${ }^{34}$ Doty SB, Matthews RS. Electron microscopic and histochemical investigation of osteogenesis imperfecta tarda. Clin Orthop 1971;80:191-201.

${ }^{35}$ Frost HM. Tetracycline-based histological analysis of bone remodelling. Calcif Tissue Res 1969;3:211-37.

${ }^{36}$ Langness $\mathrm{U}$, Behnke $\mathrm{H}$. Collagen metabolites in plasma and urine in osteogenesis imperfecta. Metabolism 1971;20:45663.

${ }^{37}$ Rosenberg E, Lang R, Boisseau V, Rojanasathit S, Avioli LV. Effect of long-term calcitonin therapy on the clinical course of osteogenesis imperfecta. J Clin Endocrinol Metab 1977;44:346-55.

${ }^{38}$ Rico Lenza H, Del Rio Vasquez A, Espinos Perez D. I'hydroxyprolinurie indice de gravité dans l'osteogenesis imperfecta tarda. Nouv Presse Med 1978; 7:3941.
${ }^{39}$ Mitoma C, Smith TE, Davidson JD, Udenfriend S, Dacosta FM, Sjoerdsma A. Improvements in methods for measuring hydroxyproline. Application to human urine. J Lab Clin Med 1959;53:970-6.

${ }^{40}$ Cattell HS, Clayton B. Failure of anabolic steroids in the therapy of osteogenesis imperfecta. J Bone Joint Surg (Am) 1968; 50: 123-41.

${ }^{41}$ Castells S, Lu C, Baker RK, Wallach S. Effects of synthetic salmon calcitonin in osteogenesis imperfecta. Curr Ther Res 1974; 16: 1-14.

${ }^{42}$ Shoenfeld Y, Fried A, Ehrenfeld NE. Osteogenesis imperfecta. Review of the literature with presentation of 29 cases. Am J Dis Child 1975;129:679-87.

${ }^{43}$ Bauze RJ, Smith R, Francis MJO. A new look at osteogenesis imperfecta. A clinical, radiological and biochemical study of forty-two patients. J Bone Joint Surg (Br) 1975;57:2-12.

4 August GP, Shapiro J, Hung W. Calcitonin therapy of children with osteogenesis imperfecta. J Pediatr 1977;91:1001-5.

${ }^{45}$ Falvo KA, Root L, Bullough PG. Osteogenesis imperfecta: clinical evaluation and management. J Bone Joint Surg (Am) 1974;56:783-93.

${ }^{46}$ Castells S, Colbert C, Chakrabarti C, Bachtell RS, Kassner EG, Yasumura S. Therapy of osteogenesis imperfecta with synthetic salmon calcitonin. J Pediatr 1979;95:807-11.

${ }^{47}$ Courpron P, Lepine P, Arlot M, Lips P, Meunier PJ. Mechanisms underlying the reduction with age of the mean wall thickness of trabecular basic structure unit (BSU) in human iliac bone. Metab Bone Dis Relat Res 1980;2(suppl):323-9.

48 Goldfield EB, Braiker BM, Prendergast JJ, Kolb FO. Synthetic salmon calcitonin. Treatment of Paget's disease and osteogenesis imperfecta. JAMA 1972;221:1127-9.

${ }^{49}$ Kocher P. Etude de l'hydroxyprolinurie dans les ostéopathies. Path Biol (Paris) 1966;14:1020-39.

${ }^{50}$ Briancon D, Meunier PJ. Treatment of osteoporosis with fluoride, calcium and vitamin D. Orthop Clin North Am 1981;12:629-48.

Requests for reprints to: Dr SA Charhon, Inserm Unité 234, Pathologie des Tissus Calcifiés, Faculté Alexis Carrel, rue G Paradin, 69008 Lyon, France. 